\title{
Analisis Kesalahan Siswa dalam Pengoperasian Bilangan Bulat
}

\author{
Ashari Najib ${ }^{1}$, Irfawandi Samad ${ }^{2}$, Muhammad Ali P. ${ }^{3}$ \\ 1,2,3 Universitas Al Asyariah Mandar; \\ e-mail: *1 asharinajib23@gmail.com, ${ }^{2}$ Ippank05@gmail.com, ${ }^{3}$ muhammad.ali.palaha@gmail.com
}

\begin{abstract}
Abstrak
Penelitian ini bertujuan mendeskripsikan analisis kesalahan siswa dalam pengoperasian Bilangan Bulat. Jenis penelitian ini adalah penelitian kualitatif dengan pendekatan deskriptif-eksploratif yang bertujuan untuk mendiskripsikan kesalahan pengoperasian bilangan yang dilakukan siswa dalam menyelesaikan soal matematika. Hasil penelitian tentang deskripsi Analisis Kesalahan Siswa dalam Pengoperasian Bilangan Bulat pada siswa Kelas VII SMP Negeri 1 Binuang dengan deskripsi kuantitatif. menunjukkan bahwa skor rata-rata hasil belajar peserta didik Kelas VII dalam Menyelesaikan Soal materi Bilangan Bulat dengan nilai rata-rata sebesar 73,2 dengan rentang skor 60 yang berarti hasil belajar matematika peserta didik kelas tersebut mulai dari 40 - 100. Median yaitu 75 dan modus atau frekuensi tertinggi yaitu 70. jumlah peserta didik yang belum tuntas belajar sebanyak 11 orang atau 44\% dan peserta didik yang belum tuntas sebanyak 14 orang atau 56\%.pengoperasian bilangan bulat untuk subjek 1 (Nf) diperoleh informasi bahwa siswa tersebut tidak mengalami kesalahan konsep, kesalahan prinsip dan kesalahan operasi. Sehingga subjek tersebut berada dalam kategori tinggi. Subjek 2 (NA) diperoleh informasi bahwa siswa tersebut tidak mengalami kesalahan prinsip dan kesalahan operasi. Sehingga subjek tersebut berada dalam kategori sedang. Dan subjek $3(\mathrm{Mr})$ diperoleh informasi bahwa siswa tersebut mengalami kesalahan konsep, prinsip dan kesalahan operasi. Sehingga subjek tersebut berada dalam kategori Rendah
\end{abstract}

Kata kunci; Analisis, Kesalahan, Pengoperasian, Bilangan Bulat

\section{PENDAHULUAN}

Matematika digunakan untuk memecahkan masalah yang dihadapi oleh manusia dalam kehidupan sehari-hari. Pentingnya matematika dalam kehidupan sehingga sesuatu yang begitu sulit sekalipun, bahkan tidak akan memungkinkan bisa hidup normal, tanpa menggunakan cara-cara matematika (Badjeber, 2011). Sehingga matematika perlu di bekalkan kepada setiap siswa sejak dasar. Mata pelajaran matematika harus di rancang tidak hanya untuk mempersiapkan siswa melanjutkan pendidikan yang lebih tinggi tetapi juga untuk memasuki dunia kerja.

Sampai saat ini, matematika masih menjadi momok yang menakutkan bagi sebagian besar siswa. Untuk itu dalam pembelajaran matematika perlu adanya pembaharuan-pembaharuan sehingga matematika menjadi pelajaran yang menarik dan menyenangkan. Kesulitan yang dialami siswa dalam memahami matematika tidak terlepas dari berbagai faktor antara lain faktor intern (siswa) dan ekstern (guru, orang tua, sekolah, masyarakat, sebagainya). Namun dalam hal ini akan dikaji faktor intern terutama dalam pengetahuan dan pemahaman siswa mengenai matematika. Minimnya pemahaman siswa terhadap konsep matematika menimbulkan kesulitan dalam menyelesaikan soal matematika (Novferma, 2016). Kesulitan itu dapat di lihat baik dalam hasil maupun dalam proses pemecahan masalah matematika. Untuk itu kita harus mengetahui letak, jenis, dan faktor apa yang menyebabkan kesalahan dalam belajar matematika sehingga dapat di peroleh solusi untuk memecahkan masalah tersebut.

Kesalahan-kesalahan yang dilakukan siswa bukan suatu hal yang kebetulan atau di sengaja. Berdasarkan observasi dan wawancara dengan guru-guru matematika, siswa yang melakukan kesalahan sebelumnya tidak di perbaiki karena faktor keterbatasan waktu dan jumlah siswa yang banyak. Bentuk kesalahan yang dilakukan siswa beraneka ragam sehingga perlu adanya analisis agar kesalahan tersebut dapat teridentifikasi dan diperbaiki. 
Dalam belajar matematika harus ada keterkaitan antara pengalaman mempelajari konsep dengan masalah di dunia nyata. Matematika mengajarkan bahwa setiap konsep berkaitan antara konsep satu dengan konsep yang lain dan menjadi prasyarat bagi konsep yang lain (Wijayanti, 2017).

Salah satu materi yang memegang peranan penting dalam pembelajaran matematika adalah operasi bilangan. Operasi bilangan merupakan materi dasar dalam pembelajaran matematika. Karena setiap materi yang ada dalam pembelajaran matematika pasti menggunakan teori bilangan. Hal ini sejalan dengan pengalaman dan wawancara peneliti dengan beberapa guru khususnya yang mengajar pada bidang studi matematika, bahwa masih banyak siswa yang mengalami kesulitan dalam mengoperasikan bilangan sehingga menimbulkan kesalahan dalam menyelesaikan soal matematika.

Dalam kamus besar Bahasa Indonesia dijelaskan bahwa kesalahan adalah penyimpangan terhadap sesuatu yang benar. Adapun defenisi lain tentang kesalahan adalah penyimpangan terhadap hal yang benar dan sifatnya sistematis, konsisten maupun insidental pada bagian tertentu. Kesalahan yang bersifat sistematis dan konsisten dipengaruhi oleh kemampuan siswa sedangkan yang bersifat insidental merupakan akibat rendahnya tingkat penguasaan materi pelajaran (Purwati, 2012). kesalahan dalam menyelesaikan soal matematika dapat dibagi menjadi tiga jenis, yaitu:

1. Kesalahan konsep adalah kesalahan dalam menggunakan konsep-konsep yang terkait dalam materi, kesalahan konsep dapat terjadi pada siswa diantaranya karna salah dalam menggunakan konsep variabel yang akan digunakan.

2. Kesalahan prinsip adalah kesalahan yang berkaitan dengan hubungan antara dua atau lebih objek-objek matematika, kesalahan prinsip dapat terjadi diantaranya karena salah dalam menggunakan rumus dan salah dalam menerjemahkan soal.

3. Kesalahan operasi adalah kesalahan dalam melakukan perhitungan, kesalahan operasi dapat terjadi karena tidak menggunakan aturan operasi atau pehitungan dengan benar.(Kahar, 2017)

Kesalahan yang dilakukan siswa dalam menyelesaikan soal matematika itu disebabkan oleh, tidak paham konsep-konsep sederhana, tidak mengetahui maksud soal, tidak bisa menerjemahkan soal ke dalam kalimat matematika, tidak bisa menyelesaikan kalimat matematika, tidak cermat dalam menghitung, dan kesalahan dalam menulis angka (Farida, 2015).

Menurut Lerner mengemukakan berbagai kesalahan umum yang dilakukan oleh anak dalam mengerjakan soal-soal matematika, yaitu kurangnya pengetahuan tentang simbol, kurangnya pemahaman tentang nilai tempat, penggunaan proses yang keliru, kesalahan perhitungan, dan tulisan yang tidak dapat dibaca sehingga siswa melakukan kekeliruan karena tidak mampu lagi membaca tulisannya sendiri (Imswatama, 2016).

\section{METODE PENELITIAN}

Jenis penelitian ini adalah penelitian kualitatif dengan pendekatan deskriptif-eksploratif yang bertujuan untuk mendiskripsikan kesalahan pengoperasian bilangan yang dilakukan siswa dalam menyelesaikan soal matematika.

Subjek penelitian ini adalah siswa kelas VII SMP dengan pertimbangan Bahwa pengetahuan dasar tentang pengoperasian bilangan bulat telah diperoleh pada bangku Sekolah Dasar. Penetapan subjek penelitian berdasarkan hasil tes awal yang dilakukan peneliti. Tiap-tiap jawaban siswa akan dianalisis kemudian ditentukan jenis-jenis kesalahan yang dilakukan siswa tersebut dalam mengoperasikan bilangan bulat. Dari hasil analisis tersebut, diambil 1 orang siswa yang mewakili tiap-tiap jenis kesalahan yang ada untuk diwawancarai.

Instrumen penelitian ini adalah peneliti sendiri yang berpandu pada pedoman wawancara dan tes diagnostik. Pedoman wawancara dibuat berdasarkan respon siswa terhadap tes diagnostik yang diberikan oleh peneliti, yang bertujuan untuk memperoleh data tentang jenis-jenis kesalahan yang dilakukan oleh siswa dalam mengoperasikan bilangan bulat.

\subsection{Prosedur Pelaksanaan Penelitian}

Secara garis besar prosedur pelaksanaan penelitian adalah sebagai berikut:

1. Orientasi lapangan 
2. Merancang instrumen penelitian

3. Validasi instrumen oleh ahli

4. Observasi lokasi penelitian

5. Penentuan subjek penelitian berdasarkan (a) hasil tes masalah dalam pengoperasian bilangan bulat, (b) rekomendasi guru matematika yang akan di wawancarai agar memudahkan dalam pengumpulan data.

6. Pengumpulan data meliputi (a) memberikan tes kemampuan awal berupa tes tulis, (b) wawancara berdasarkan hasil tes awal yang mengenai pengoperasian bilangan bulat, (c) triangulasi.

7. Analisis data, meliputi (a) menganalisis hasil tes kemampuan awal yang berupa tes tulis (b) menganalisis hasil wawancara untuk mengetahui deskripsi kesalahan yang dilakukan oleh siswa.

8. Menyusun laporan akhir penelitian.

\subsection{Teknik Analisis Data}

Teknik analisis data dalam penelitian ini menggunakan metode seperti yang dikemukakan oleh Miles dan Huberman dengan langkah-langkah sebagai berikut:

1. Reduksi data dalam penelitian ini meliputi:

a. Mengoreksi hasil pekerjaan siswa, kemudian mengkategorikan jenis-jenis kesalahan pengoperasian bilangan bulat yang dilakukan oleh siswa.

b. Mendeskripsikan jenis-jenis kesalahan siswa yang menjadi subjek penelitian dengan wawancara.

c. Menyederhanakan hasil wawancara menjadi susunan bahasa yang baik dan rapi, kemudian mentransformasikan ke dalam catatan.

2. Penyajian data dalam penelitian ini meliputi:

a. Menyajikan hasil pekerjaan siswa yang dijadikan bahan untuk wawancara.

b. Menyajikan hasil wawancara yang telah direkam pada tape recorder.

c. Dari hasil penyajian data dilakukan analisis. Kemudian disimpulkan yang berupa data temuan, sehingga mampu menjawab permasalahan dalam penelitian ini.

3. Menarik kesimpulan atau verifikasi

Verifikasi pada penelitian ini dilakukan dengan cara membandingkan hasil pekerjaan siswa dan hasil wawancara yang dilakukan oleh peneliti, sehingga dapat ditarik kesimpulan tentang deskripsi kesalahan pengoperasian bilangan bulat yang dilakukan oleh siswa (Sulistyaningsih, 2017).

\section{HASIL DAN PEMBAHASAN}

Hasil penelitian tentang deskripsi Analisis Kesalahan Siswa dalam Pengoperasian Bilangan Bulat pada siswa Kelas VII SMP Negeri 1 Binuang dengan deskripsi kuantitatif. Hasil ini diperoleh siswa setelah mengerjakan tes berupa soal materi pokok tentang Bilangan Bulat. Analisis statistik ini dimaksud untuk mendeskripsikan analisis kesalahan dalam Menyelesaikan Soal pada materi Bilangan Bulat.

Tabel 1 Statistik Hasil Belajar Matematika pada Materi Bilangan Bulat

\begin{tabular}{|c|c|}
\hline Statistik & Nilai Statistik \\
\hline Subjek Penelitian & 25,00 \\
\hline Skor Rata-Rata & 73,20 \\
\hline Skor Tertinggi & 100,00 \\
\hline Skor Terendah & 40,00 \\
\hline Rentang Skor & 60,00 \\
\hline Median & 77,00 \\
\hline Modus & 70,00 \\
\hline Standar Deviasi & 12,49 \\
\hline
\end{tabular}

Sumber data: Hasil analisis hasil belajar Kelas VIII SMP Negeri 1 Binuang

Berdasarkan tabel 1 menunjukkan bahwa skor rata-rata hasil belajar peserta didik Kelas VII dalam Menyelesaikan Soal materi Bilangan Bulat dengan nilai rata-rata sebesar 73,2 dengan rentang skor 60 yang 
berarti hasil belajar matematika peserta didik kelas tersebut mulai dari 40 - 100. Median yaitu 75 dan modus atau frekuensi tertinggi yaitu 70 .

Apabila skor hasil belajar peserta didik dalam Menyelesaikan Soal pada materi Bilangan Bulat dianalisis kedalam persentase ketuntasan belajar, maka dapat dilihat pada tabel 2 berikut:

Tabel 2 Distribusi frekuensi ketuntasan

\begin{tabular}{|c|c|c|c|c|}
\hline No. & Nilai & Frekuensi & $(\%)$ & \\
\hline 1. & $0 \leq$ skor $<73$ & 11 Orang & $44 \%$ & Belum Tuntas \\
\hline 2. & $73 \leq$ skor $<100$ & 14 Orang & $56 \%$ & Tuntas \\
\hline
\end{tabular}

Sumber data: Hasil analisis hasil belajar Kelas VII SMP Negeri 1 Binuang

Berdasarkan tabel 2 dapat dilihat bahwa jumlah peserta didik yang belum tuntas belajar sebanyak 11 orang atau $44 \%$ dan peserta didik yang belum tuntas sebanyak 14 orang atau $56 \%$.

Dari hasil pengelolaan data hasil tes pada materi bilangan bulat dengan menggunakan statistik deskriptif, dengan jumlah siswa 25 orang. Di peroleh hasil jawaban yang berbeda, dan diambil 3 orang siswa untuk mewakili 3 kategori, kategori tinggi, sedang dan rendah.

\subsection{Untuk Subjek 1 (Nf) Kategori Tinggi}

Berdasarkan pertanyaan pada materi ajar pengoperasian bilangan bulat untuk subjek 1 (Nf) diperoleh informasi bahwa siswa tersebut tidak mengalami kesalahan konsep, kesalahan prinsip dan kesalahan operasi. Sehingga subjek tersebut berada dalam kategori tinggi.

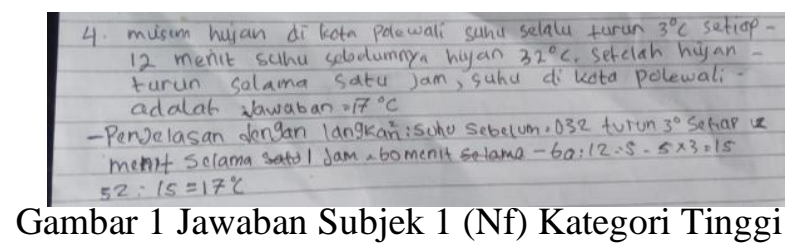

Untuk meyakini asumsi peneliti terhadap analisis kesalahan siswa dalam pengoperasian bilangan bulat maka peneliti melakukan wawancara terhadap subjek 1 (Nf). Wawancara dilakukan dengan memperhatikan hasil tes tertulis. Berikut penggalan wawancara peneliti.

P : Bacakan soalnya!

$\mathrm{Nf} \quad$ : musim hujan di kota polewali suhu selalu turun $3^{\circ} \mathrm{C}$ setiap 12 menit. Suhu sebelum hujan $32{ }^{\circ} \mathrm{C}$. setelah hujan turun selama satu jam, suhu di kota polewali adalah...

$\mathrm{P} \quad$ : coba jelaskan apa yang diketahui dalam soal !

$\mathrm{Nf} \quad$ : yang pertama itu kak suhu sebelum hujan $=32{ }^{\circ} \mathrm{C}$, baru kedua suhu selalu turun $3{ }^{\circ} \mathrm{C}$ dalam 12 menit, dan ini yang 1 jam kak di ubah ke menit jadinya 60 menit

$\mathrm{P} \quad$ : coab jelaskan apa yang ditanyakan pada soal!

$\mathrm{Nf} \quad$ : suhu di kota polewali setelah hujan turun selama 1 jam

$\mathrm{P} \quad$ : Coba tulisPan kaimat matematika dari soal tersebut

$\mathrm{Nf}: 32-60: 12 \times 3$

$\mathrm{P} \quad$ : coba sebuatkan ada berapa operasi hitung yang kamu gunakan untuk menyelesaikan soal tersebut ?

$\mathrm{Nf} \quad$ : ada tiga kaka, pengurangan, pembagian dan perkalian

$\mathrm{P} \quad$ : Apabila terdapat operasi penjumlahan (+) dan pengurangan (-) bertemu operasi perkalian (x) dan pembagian (:) apakah yang di seesaikan terlebih dahulu adalah operasi penjumlahan $(+)$ dan pengurangan (-) ?

$\mathrm{Nf} \quad$ : tidak kak, harusnya perkalian sama pembagian yang pertama

$\mathrm{P} \quad$ : apabila terdapat operasi penjumlahan (+) dan perkalian (x) yang manakah yang terlebih dahulu di slesaikan?

$\mathrm{Nf} \quad$ : perkalian duluan kak

$\mathrm{P} \quad$ : apakah opesai perkalian (x) dan pembagian (:) itu sama besar ?

$\mathrm{Nf} \quad$ : iya

P : jika bilangan bulat (-) dikalikan dengan bilagan bulat (+) maka hasilnya adalah ? 
Pada hasil wawancara terdapat kesimpulan, berdasarkan dari tiga aspek kesalahan yatu kesalahan konsep, prinsip dan kesalahan operasi siswa tersebut tidak memiliki kesalahan dalam menjawab soal itu terbukti berdasarkan penggalan wawancara diatas.

\subsection{Untuk Subjek 2 (NA) Kategori Sedang}

Berdasarkan pertanyaan pada materi ajar pengoperasian bilangan bulat untuk subjek 2 (NA) diperoleh informasi bahwa siswa tersebut tidak mengalami kesalahan prinsip dan kesalahan operasi. Sehingga subjek tersebut berada dalam kategori sedang.

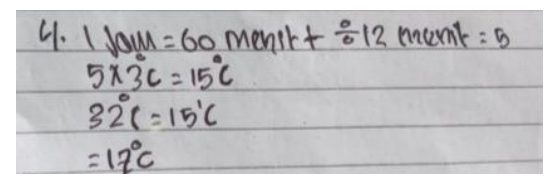

Gambar 2 Jawaban Subjek 2 (NA) Kategori Sedang

Untuk meyakini asumsi peneliti terhadap analisis kesalahan siswa dalam pengoperasian bilangan bulat maka peneliti melakukan wawancara terhadap subjek 2 (NA). Wawancara dilakukan dengan memperhatikan hasil tes tertulis. Berikut penggalan wawancara peneliti.

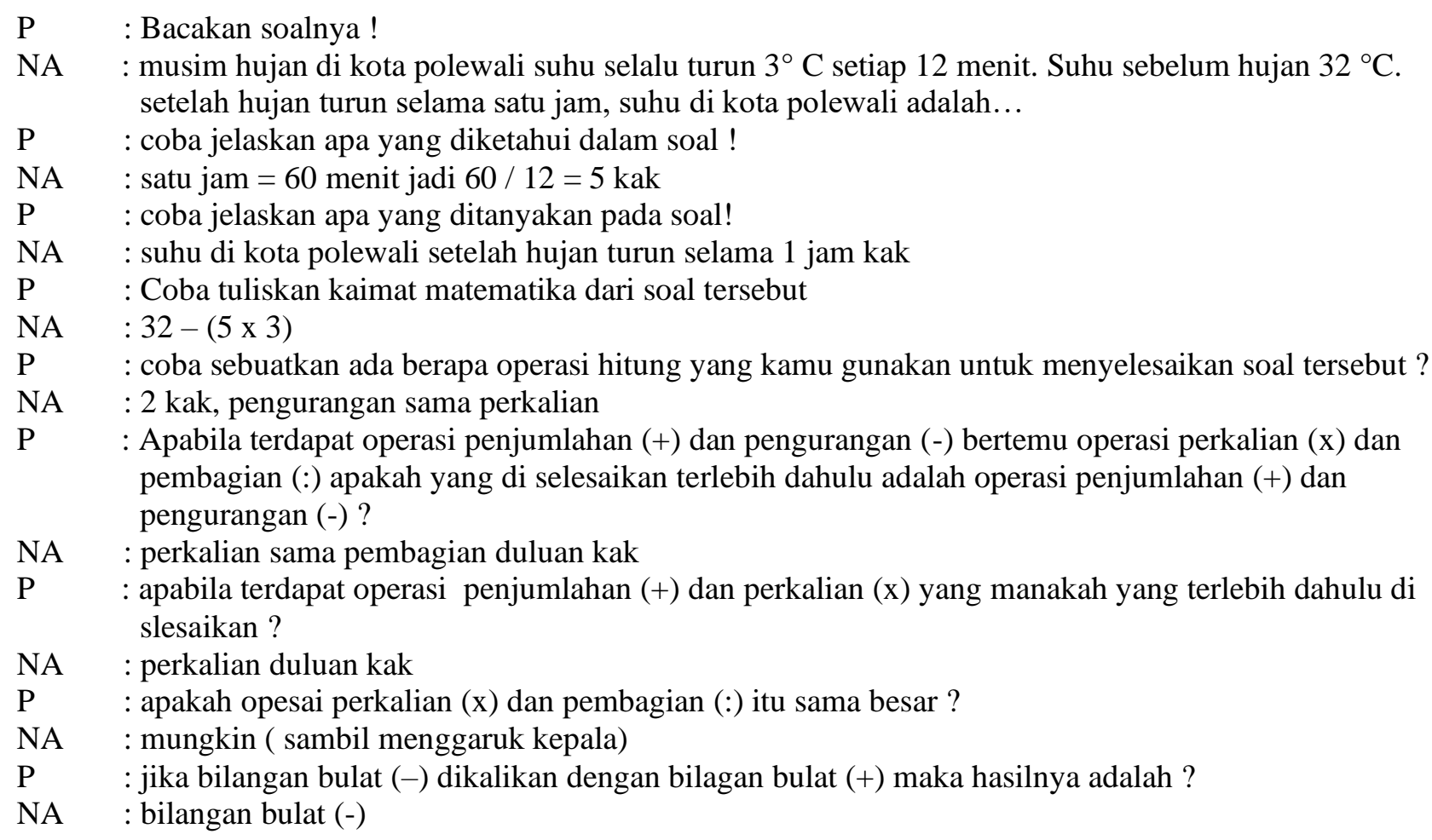

Pada hasil wawancara terdapat kesimpulan, berdasarkan dari tiga aspek kesalahan yaitu kesalahan konsep, prinsip dan kesalahan operasi siswa tersebut masih memiliki kesalahan pada konsep karena belum mengetahui apa saja yang di ketahui pada soal dan dan belum memahami kesetaraan pada operasi perkalian dan pembagian. Pada kesalahan prinsip masih masih kurang dalam menyusun kalimat matematika

\subsection{Untuk Subjek $3(\mathrm{Mr})$ Kategori Rendah}

Berdasarkan pertanyaan pada materi ajar pengoperasian bilangan bulat untuk subjek 3 (Mr) diperoleh informasi bahwa siswa tersebut mengalami kesalahan konsep, prinsip dan kesalahan operasi. Sehingga subjek tersebut berada dalam kategori Rendah. 


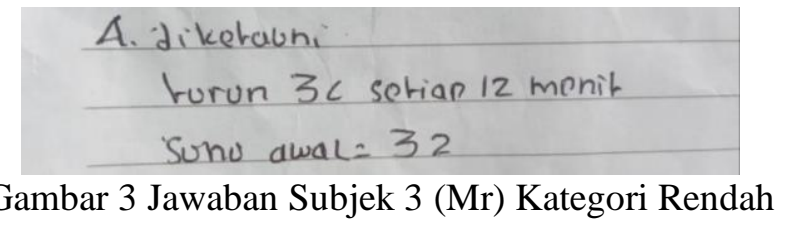

Untuk meyakini asumsi peneliti terhadap analisis kesalahan siswa dalam pengoperasian bilangan bulat maka peneliti melakukan wawancara terhadap subjek 3 (Mr). Wawancara dilakukan dengan memperhatikan hasil tes tertulis. Berikut penggalan wawancara peneliti.

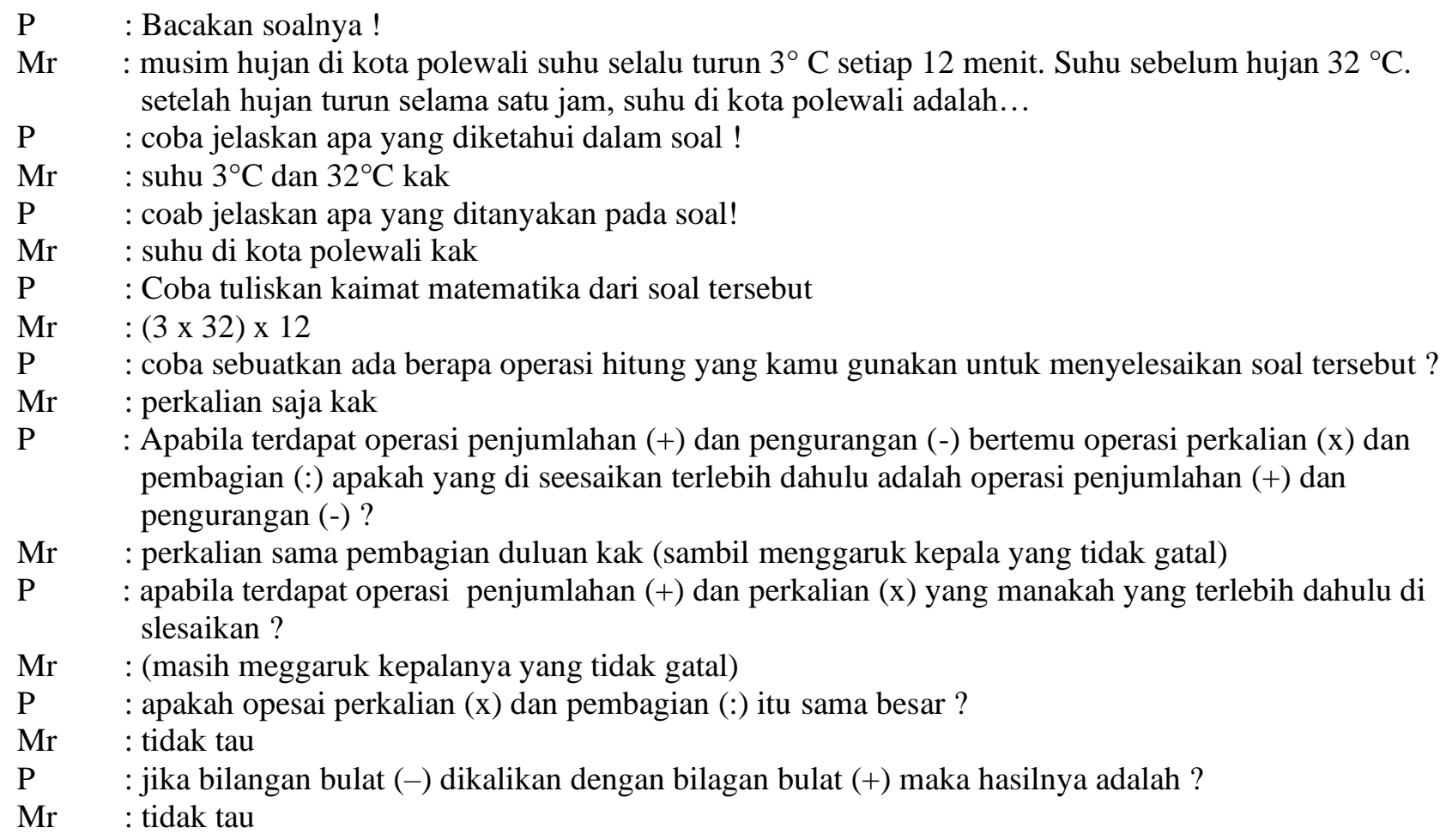

Pada hasil wawancara terdapat kesimpulan, berdasarkan dari tiga aspek kesalahan yatu kesalahan konsep, prinsip dan kesalahan operasi, siswa tersebut belum memahami konsep, prinsip dan operasi dalam bilnagn bulat itu dilihat dari beberapa penggalan wawancara.

\section{KESIMPULAN}

Berdasarkan hasil Analisis data dalam penelitian ini, maka dapat ditarik kesimpulan sebagai berikut: Hasil penelitian tentang deskripsi Analisis Kesalahan Siswa dalam Pengoperasian Bilangan Bulat pada siswa Kelas VII SMP Negeri 1 Binuang dengan deskripsi kuantitatif. Menunjukkan bahwa skor rata-rata hasil belajar peserta didik Kelas VII dalam Menyelesaikan Soal materi Bilangan Bulat dengan nilai rata-rata sebesar 73,2 dengan rentang skor 60 yang berarti hasil belajar matematika peserta didik kelas tersebut mulai dari 40 - 100 . Median yaitu 75 dan modus atau frekuensi tertinggi yaitu 70. Jumlah peserta didik yang belum tuntas belajar sebanyak 11 orang atau $44 \%$ dan peserta didik yang belum tuntas sebanyak 14 orang atau 56\%. Pengoperasian bilangan bulat untuk subjek 1 (Nf) diperoleh informasi bahwa siswa tersebut tidak mengalami kesalahan konsep, kesalahan prinsip dan kesalahan operasi. Sehingga subjek tersebut berada dalam kategori tinggi.subjek 2 (NA) diperoleh informasi bahwa siswa tersebut tidak mengalami kesalahan prinsip dan kesalahan operasi. Sehingga subjek tersebut berada dalam kategori sedang. Dan subjek 3 (Mr) diperoleh informasi bahwa siswa tersebut mengalami kesalahan konsep, prinsip dan kesalahan operasi. Sehingga subjek tersebut berada dalam kategori Rendah. 
https://jurnal.unsulbar.ac.id/index.php/saintifik

\section{DAFTAR PUSTAKA}

Badjeber, Rafiq. 2011. Penerapan Metode Penemuan Terbimbing Untuk Meningkatkan Hasil Belajar Siswa Kelas VII Ki Hajar Dewantoro SMP Negeri 4 Palu Pada Materi Hubungan Antar Sudut. Skripsi Tidak Diterbitkan. Palu: FMIPA UNTAD.

Farida, N. (2015). Analisis kesalahan siswa SMP kelas VIII dalam menyelesaikan masalah soal cerita matematika. AKSIOMA: Jurnal Program Studi Pendidikan Matematika, 4(2).

Imswatama, A. (2016). Analisis kesalahan mahasiswa dalam menyelesaikan soal geometri analitik bidang materi garis dan lingkaran. Suska Journal of Mathematics Education, 2(1), 1-12.

Kahar, M. S., \& Layn, M. R. (2017). Analisis Kesalahan Siswa Dalam Menyelesaikan Soal Cerita Matematika. Jurnal Math Educator Nusantara: Wahana Publikasi Karya Tulis Ilmiah di Bidang Pendidikan Matematika, 3(2), 95-102.

Novferma, N. 2016. Analisis Kesulitan dan Self-Efficacy Siswa SMP dalam Pemecahan Masalah Matematika Berbentuk Soal Cerita. Jurnal Riset Pendidikan Matematika. Volume 3. No.1

Purwati. 2012. Analisis Kesalahan Siswa Dalam Menyelesaikan Masalah Lingkaran Berdasarkan Kriteria Watson pada Siswa Kelas X SMA Negeri 1 Sabbang. TesisProgram Pascasarjana Universitas Negeri Makassar tidak diterbitkan

Sulistyaningsih, A., \& Rakhmawati, E. (2017). Analisis Kesalahan Siswa Menurut Kastolan Dalam Pemecahan Masalah Matematika. In Pembelajaran Matematika Berbasis TIK untuk Meningkatkan Literasi Matematika: Peluang dan Tantangan: Prosiding Seminar Nasional Matematika dan Pendidikan Matematika.

Wijayanti, A. E. (2017). Analisis Kesulitan Siswa Kelas Dua SDN Wonoplintahan II dalam Pemecahan Masalah Pembagian Bilangan Dua Angka. Universitas Muhammadiyah Sidoarjo. 